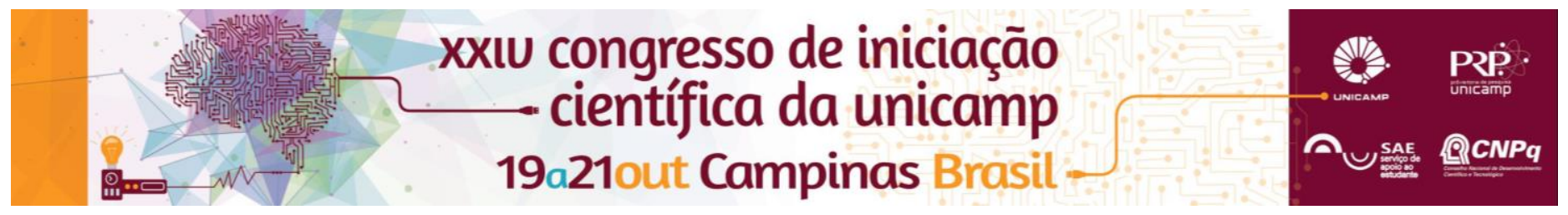

\title{
Arte e Paisagem em Inhotim: distintas formas de interlocução de trabalhos tridimensionais apresentados na Natureza.
}

\author{
Marcelo Deniz Scaglia - Orient: Prof ${ }^{a}$. Drª. Sylvia Helena Furegatti
}

\begin{abstract}
Resumo
A pesquisa busca investigar e entender algumas das formas com as quais as obras artísticas tridimensionais podem ser apresentadas em diálogo direto com a Natureza. Para isso, foi elaborado um recorte que enfoca o Centro de Arte Contemporânea Inhotim, sediado na cidade de mesmo nome, em Minas Gerais. Atualmente é considerado por muitos como o maior museu ao ar livre da América Latina. A partir dessa coleção foram eleitos três artistas: Cristina Iglesias, Giuseppe Penone e Marilá Dardot e seus trabalhos que interagem com os ambientes de jardim e a Natureza ao redor daquele Centro de Arte. Os projetos criam poéticas particulares para essa relação arte-naturezaao mesmo tempo que, díspares, apresentam-se pertinentes aos contextos poéticos desenvolvidos por cada um dos artistas em questão.
\end{abstract}

\section{Palavras-chave:}

Escultura, Inhotim, Natureza.

\section{Introdução}

A coleção de trabalhos de arte em meio à Natureza pode ser lida como uma das principais propostas do Centro de Arte Contemporânea Inhotim. Vários artistas, de diferentes regiões do Brasil e diferentes países, expõem seus trabalhos nesse espaço a céu aberto e dialogam, de alguma forma, com a natureza ali presente. Cada trabalho dessa extensa coleção segue uma linha poética diferente ao estabelecer essa relação. Dentre os artistas eleitos, cada um trabalha uma poética bastante pessoal, que acaba por encantar os olhos dos visitantes, que se deslumbram pelo encontro da Arte com 0 ambiente natural, longe das cidades e fora do arquétipo tipificador do museu. Marilá Dardot, Giuseppe Penone e Cristina Iglesias trazem para a atmosfera do Centro de Artes do Inhotim três obras que respeitam o seu ambiente e dialogam com ele de formas variadas que podem, até mesmo, serem comparadas ao Comensalismo do campo da Ecologia, ou seja, relação benéfica entre organismos de espécies diferentes que coabitam a natureza.

\section{Resultados e Discussão}

Para esse projeto foi realizado um estudo de campo com destino ao Centro Inhotim, para se apreender mais da ideia geral que continha o recorte pesquisado. Um encontro de fato com as obras era necessário para entender como a Arte convergia com a Natureza ao seu redor, trazendo aqui o questionamento de quando o meio se fazia, de fato, necessário para a contextualização dos trabalhos ali instalados. Isso porque é notável que, algumas obras desse Centro poderiam estar situadas em um museu urbano sem que sua poética fosse adulterada, enquanto outras (caso particular das três obras estudadas nessa pesquisa) perderiam totalmente o propósito uma vez colocadas fora de seu lugar em meio à paisagem natural.

O’DOHERTY, Brian, No Interior Do Cubo Branco, São Paulo: Martins Fontes, 2002 .
Figura 1. Elevazione, de Giuseppe Penone.

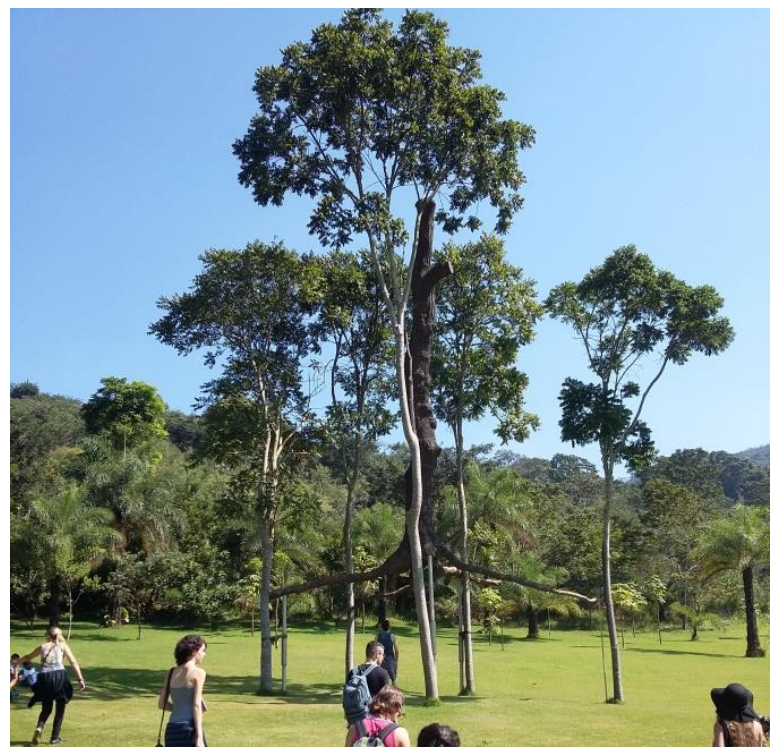

\section{Conclusões}

Em arte, é necessário entender o que o artista pretende exprimir ou alcançar com sua obra. Os três artistas selecionados para esse projeto evidenciam para seus leitores/expectadores uma relação de forte dependência para com a Natureza, que ao momento distinto, as ideias por trás das obras revelam se em sua constante troca com o ambiente, uma relação que é sustentada pela sua instalação na paisagem. Em cada proposição artística, por meios e formas diferentes, deixam clara a conexão entre a Arte e seu entorno, quase que pautado por uma ação muito sutil, algo invisível da ação do homem.

\section{Agradecimentos}

Agradeço à minha orientadora Sylvia Helena Furegatti pelo suporte durante a pesquisa, à Caio Victor que ajudou a tornar a viagem para o Centro Inhotim possível e à $\mathrm{CNPq}$ e ao SAE que forneceram a oportunidade de realizar a pesquisa. 